\title{
PENGETAHUAN MASYARAKAT UMUM DAN MASYARAKAT SANTRI TERHADAP BANK SYARIAH Studi Kasus Kemukiman Bandar Baru Kecamatan Banda Baro Kabupaten Aceh Utara
}

\author{
MUHAMMAD NASIR, MUKHLIS DAN MISKARINA \\ Dosen pada Politeknik Negeri Lhokseumawe
}

Islamic Banking is a bank that runs its main activity to gather funds from community and to funneling funds to community based on the principles of Shariah. This study discusse about the knowledge of the general public and the islamic students toward Islamic banking. The purpose of this research is to find out how the knowledge of the general public and the islamic students toward Islamic banking. The objects of this research are community general public and Islamic student in Kemukiman Bandar Baru. For the general public is composed of five villages, are: Cot Jabet, Ulee Nyeue, Paya Uleue, Alue Keurinyai and Jamuan. For Islamic Students consists of Integrated Dayah Darul Ma'rifah and Recitation Hall Babussalam Al-Aziziyah. The Data used in this research is the primary data obtained through interviews of respondents directly by using the questionnaire. In the sample, methods used is probability sampling and to define samples in research is used technique stratified sampling and engineering clusters of sampling.Hence, samples are obtained for the general public and islamic students for each are 100 respondents. Test statistics instrument used for analysis this research is test different samples average two pairs (paired sampels test). Test result average difference suggests that there is a difference of knowledge among the general public and the islamic students of Islamic banking. This suggests that the knowledge society students are still less aware of Islamic banking. The implication may provide opportunities to the existing Islamic banking in the community to conduct socialization to society, particularly the Islamic students.

Keywords: General Public, Islamic students, Islamic Banking 


\section{PENDAHULUAN}

Kehadiran bank syariah memperkuat peran serta industri perbankan dalam pembangunan perekonomian Indonesia dan menjaga stabilitas keuangan nasional, sehingga perlu adanya pengembangan perbankan syariah untuk menciptakan bank syariah yang kuat dan sehat serta berdaya saing tinggi. Namun, masih terdapat perbedaan antara bank yang murni syariah dengan bank konvensional yang berbasis syariah. Salah satunya, bank yang murni syariah telah melaksanakan sepenuhnya sistem syariah sedangkan bank konvensional yang berbasis syariah belum sepenuhnya menerapkan sistem syariah.

Saat ini bank syariah sudah memiliki ribuan cabang dan unit-unit syariah yang tersebar di beberapa kota besar di Indonesia seperti Jakarta, Makassar, Surabaya, Bandung, Banda Aceh dan kota-kota lainnya. Untuk wilayah Aceh, perkembangan syariah semakin meningkat, terbukti dengan hadirnya bank-bank syariah di Aceh. Peranan perbankan syariah di Aceh sangat membantu masyarakat dalam sistem perekonomiannya, mengingat Provinsi Aceh identik dengan syariah Islam, sehingga hal tersebut berdampak positif terhadap pengembangan dan perluasan jaringan bank syariah dalam menghimpun dana dan menyalurkan dana.

Aceh Utara adalah sebuah kabupaten yang terletak di provinsi Nanggroe Aceh Darussalam, Indonesia. Ibukota kabupaten ini dipindahkan dari Lhokseumawe ke Lhoksukon, menyusul dijadikannya Lhokseumawe sebagai kota otonom. Aceh Utara juga merupakan wilayah dengan jumlah perangkat administratif paling besar yang memiliki 27 kecamatan, 67 mukim dan 852 gampong (Aceh Dalam Angka : 2013). Dalam kabupaten ini yang menjadi objek penelitian adalah Kecamatan Banda Baro Kemukiman Bandar Baru. Oleh karena itu, dari permasalahan di atas ikut dialami oleh masyarakat daerah Kemukiman Bandar Baru Kecamatan Banda Baro-Aceh Utara, yang tinggal jauh dari lembaga perbankan syariah, terutama masyarakat umum dan masyarakat santri. Masyarakat tersebut tentunya pernah mendengar tentang bank syariah atau sebagian pernah menggunakan jasa bank syariah untuk keperluan priba- di, agar mempermudah dalam menginvestasikan dananya.

\section{Tujuan Penelitian}

Berdasarkan perumusan masalah di atas, maka tujuan penelitian ini adalah untuk mengetahui tentang pengetahuan masyarakat umum dan masyarakat santri terhadap Bank Syariah (Studi Kasus Kemukiman Bandar Baru Kecamatan Banda Baro - Aceh Utara).

\section{Dasar Hukum Bank Syariah}

Dalam kaidah hukum yang berlaku disebutkan bahwa semua hal dilarang, kecuali yang ada ketentuannya berdasarkan Al-Quran dan Al-hadits. Sedangkan dalam prinsip hukum muamalah, semua diperbolehkan kecuali ada dalil yang melarangnya. Menurut Yaya (2009), Prinsip-prinsip hukum muamalah tersebut, diantaranya:

a. Prinsip mubah, yaitu segala bentuk muamalah disebutkan mubah kecuali yang ditentukan lain oleh Al-Quran dan Sunnah Rasul;

b. Prinsip sukarela, yaitu muamalah dilakukan atas dasar sukarela tanpa mengandung unsurunsur paksaan;

c. Prinsip mendatangkan manfaat dan menghindarkan mudarat, yaitu muamalah yang dilakukan atas dasar pertimbangan mendatangkan manfaat dan menghindarkan mudarat dalam kehidupan masyarakat;

d. Prinsip keadilan, muamalah dilakukan dengan memelihara nilai keadilan, menghindari unsurunsur penganiayaan, unsur-unsur pengambilan kesempatan dalam kesempitan.

\section{Produk dan Jasa Perbankan Syariah \\ 1. Produk Penyaluran Dana}

Penyaluran dana kepada nasabah, secara garis besar produk pembiayaan syariah terbagi ke dalam empat kategori yang dibedakan berdasarkan tujuan penggunaanya, yaitu:

a. Pembiayaan dengan Prinsip Jual Beli (Ba'i)

Transaksi jual-beli dapat dibedakan berdasarkan bentuk pembayarannya dan waktu penyerahan barangnya, yakni sebagai berikut:

- Pembiayaan Murabahah (al-ba'i bi tsaman ajil) adalah transaksi jual-beli di mana bank menyebut jumlah keuntungannya. Bank 
bertindak sebagai penjual, sementara nasabah sebagai pembeli. Harga jual adalah harga beli bank dari pemasok ditambah keuntungan (margin).

- Pembiayaan Salam adalah transaksi jual beli di mana barang yang diperjualbelikan belum ada. Akan tetapi, barang diserahkan secara tangguh sementara pembayaran dilakukan tunai. Bank bertindak sebagai pembeli, sementara nasabah sebagai penjual. Transaksi ini mirip dengan ijon, namun dalam transaksi ini kuantitas, kualitas, harga dan waktu penyerahan barang harus ditentukan secara pasti.

- Pembiayaan Istishna' menyerupai produk saham, tetapi dalam Istishna' pembayarannya dapat dilakukan oleh bank dalam beberapa kali (termin) pembayaran. Secara umum, pembiayaan ini diaplikasikan pada pembiayaan manufaktur dan kontruksi.

Ketentuan umum pembiayaan Istishna' adalah spesifikasi barang pesanan harus jelas seperti jenis, macam ukuran, mutu dan jumlahnya. Harga jual yang telah disepakati dicantumkan dalam akad istishna' dan tidak boleh berubah selama berlakunya akad. Apabila terjadi perubahan dari kriteria pesanan dan terjadi perubahan harga setelah akad ditandatangani, maka seluruh biaya tambahan ditanggung oleh nasabah.

b. Pembiayaan dengan Prinsip Sewa (Ijarah)

Ijarah adalah akad perpindahan hak guna atas barang atau jasa, melalui pembayaran upah sewa tanpa diikuti dengan pemindahan kepemilikan atas barang itu sendiri. Pada dasarnya prinsip ijarah sama seperti prinsip jual beli, tapi perbedaannya terletak pada objek transaksinya. apabila jual beli objek transaksinya berupa barang, maka pada ijarah objek transaksinya berupa jasa.

Pada akhir masa sewa, bank dapat saja menjual barang yang disewakannya kepada nasabah. transaksi ini disebut dengan Ijarah Muntahia Bittamlik (perpaduan antara kontrak jual beli adan sewa atau lebih tepatnya akad sewa yang diakhiri dengan kepemilikan barang di tangan si penyewa.

c. Pembiayaan dengan Prinsip Bagi Hasil

(Syirkah)

Produk pembiayaan syariah yang didasarkan atas prinsip bagi hasil adalah sebagai berikut:
- Pembiayaan Musyarakah adalah Akad kerja sama di antara dua pihak atau lebih untuk suatu usaha tertentu yang masing-masing pihak memberikan porsi dana dengan ketentuan bahwa keuntungan akan dibagi sesuai dengan kesepakatan, sedangkan kerugian ditanggung sesuai dengan porsi dana masing-masing (Penjelasan Pasal 19 ayat (1) huruf c UU No. 21 Tahun 2008).

Secara spesifik bentuk kontribusi dari pihak yang bekerja sama dapat berupa dana, barang perdagangan (trading asset), kewiraswastaan (entrepreneurship), kepandaian (skill), kepemilikan (property), peralatan (equipment), atau intangible asset (seperti hak cipta atau goodwill), kepercayaan/reputasi (credit worthiness) dan barang-barang lainnya yang dapat dinilai dengan uang.

- Pembiayaan Mudharabah adalah akad kerja sama suatu usaha antara pihak pertama (malik, shahibul mal, atau Bank Syariah) yang menyediakan seluruh modal dan pihak kedua ('amil, mudharib, atau Nasabah) yang bertindak selaku pengelola dana dengan membagi keuntungan usaha sesuai dengan kesepakatan yang dituangkan dalam Akad, sedangkan kerugian ditanggung sepenuhnya oleh Bank Syariah kecuali jika pihak kedua melakukan kesalahan yang disengaja, lalai atau menyalahi perjanjian (Penjelasan Pasal 19 ayat (1) huruf c UU No. 21 Tahun 2008).

\section{Produk Penghimpunan Dana}

Penghimpunan dana di Bank Syariah dapat berbentuk giro, tabungan, dan deposito. Prinsip operasional syariah yang diterapkan dalam penghimpunan dana masyarakat adalah pinsip Wadi'ah dan Mudharabah.

\section{a. Prinsip Wadi'ah}

Wadi'ah adalah titipan murni dari satu pihak ke pihak lain, baik individu maupun badan hukum, yang harus dijaga dan dikembalikan kapan saja si penitip menghendaki. Prinsip wadi'ah yang diterapkan adalah wadi'ah yad dhamanah pada produk rekening giro, artinya pihak yang menerima titipan boleh menggunakan dan memanfaatkan uang atau barang yang dititipkan. Tentunya pihak bank dalam hal ini mendapatkan bagi hasil dari 
penggunaan dana dan bank dapat memberikan insentif kepada penitip dalam bentuk bonus.

Sedangkan prinsip wadi'ah yad amanah, yaitu pihak yang menerima tidak boleh menggunakan dan memanfaatkan uang atau barang yang dititipkan, tetapi harus benar-benar menjaganya sesuai kelaziman. Pihak penerima titipan dapat membebankan biaya kepada penitip sebagai biaya penitipan.

\section{b. Prinsip Mudharabah}

Mudharabah adalah akad kerja sama antara pihak pertama (malik, shahibul mal, atau Nasabah) sebagai pemilik dana dan pihak kedua ('amil, mudharib, atau Bank Syariah) yang bertindak sebagai pengelola dana dengan membagi keuntungan usaha sesuai dengan kesepakatan yang dituangkan dalam Akad (Penjelasan Pasal 19 ayat (1) huruf b UU No. 21 Tahun 2008).

\section{Jasa Perbankan Syariah}

Selain menjalankan fungsinya sebagai intermediaries (penghubung) antara pihak yang membutuhkan dana (deficit unit) dengan pihak yang kelebihan dana (surplus unit), bank syariah dapat pula melakukan berbagai pelayanan jasa perbankan kepada nasabah dengan mendapatkan imbalan berupa sewa atau keuntungan. Jasa-jasa yang diberikan bank syariah yaitu:

\section{a. Prinsip Wakalah (Perwakilan)}

Wakalah berarti penyerahan, pendelegasian, atau pemberian mandat (Antonio, 2001). Dalam konteks muamalah, wakalah adalah pelimpahan kekuasaan oleh seseorang (muwakkil) kepada yang lain (wakil) dalam hal-hal yang diwakilkan. Wakalah dalam aplikasi perbankan terjadi apabila nasabah memberikan kuasa kepada bank untuk mewakili dirinya melakukan pekerjaan jasa tertentu, seperti pembukaan L/C, inkaso, transfer uang, transfer valuta asing, setoran kliring, kliring antarkota, pajak online dan pajak impor.

\section{b. Prinsip Kafalah (Garansi Bank)}

Kafalah merupakan jaminan yang diberikan oleh penanggung (kafil) kepada pihak ketiga untuk memenuhi kewajiban pihak kedua atau yang ditanggung (makfuul 'anhu 'ashil) (Antonio, 2001). Kafalah dapat diberikan dengan tujuan untuk menjamin pembayaran suatu kewajiban pembayaran. Untuk jasa ini, bank mendapatkan peng- ganti biaya atas jasa yang diberikan.

c. Prinsip Hiwalah (Alih Utang-Piutang)

Hiwalah adalah pengalihan utang dari orang yang berutang (muhil) kepada orang lain yang menanggungnya (muhal 'alaih). Tujuan produk hiwalah adalah untuk membantu supplier mendapatkan modal tunai agar dapat melanjutkan produksinya. Bank mendapat ganti-biaya atas jasa pemindahan piutang. Untuk mengantisipasi risiko kerugian yang akan timbul, bank melakukan penelitian atas kemampuan pihak yang berutang dan kebenaran transaksi antara yang memindahkan piutang dengan yang berutang.

d. Prinsip Sharf(Jual Beli Valuta Asing)

Prinsip Sharf adalah suatu prinsip yang digunakan dalam transaksi jual beli mata uang, baik antarmata uang sejenis maupun antarmata uang berlainan jenis. Untuk mata uang yang berlainan jenis, penyerahan uangnya harus dilakukan pada waktu yang sama dan bank memperoleh keuntungan dari jual beli asing ini.

e. Prinsip Ijarah (Sewa)

Prinsip ijarah merupakan prinsip yang sangat banyak digunakan dalam pelaksanaan fungsi jasa keuangan bank syariah. Berdasarkan fatwa DSN No. 9 Tahun 2000, disebutkan bahwa objek ijarah adalah manfaat dari penggunaan barang dan/atau jasa. Ijarah bila diterapkan untuk mendapatkan manfaat barang disebut sewa-menyewa, sedangkan bila diterapkan untuk mendapatkan manfaat orang disebut upah mengupah (Karim, Adiwarman A. : 2004).

Jenis kegiatan ijarah antara lain penyewaan kotak simpanan (save deposit box), jasa tata laksana administrasi dokumen (custodian), kartu ATM, SMS banking, pembayaran tagihan dan pembayaran gaji elektronik.

f. Prinsip Rahn (Gadai)

Rahn adalah menahan salah satu harta milik si peminjam sebagai jaminan atas pinjaman yang diterimanya (Muhammad Syafi'i Antonio, 2001). Tujuan rahn adalah untuk memberikan jaminan pembayaran kembali kepada bank dalam memberikan pembiayaan. Barang yang ditahan tersebut memiliki nilai ekonomis. Barang yang digadaikan wajib memenuhi kriteria, yaitu milik nasabah sendiri, jelas ukuran, sifat, dan nilainya ditentukan berdasarkan nilai riil pasar, serta dapat 
dikuasai namun tidak boleh dimanfaatkan oleh bank.

\section{g. Prinsip Qard}

Qard adalah pemberian harta kepada orang lain yang dapat ditagih atau diminta kembali atau dengan kata lain meminjamkan tanpa mengharapkan imbalan (Antonio, 2001). Salah satu aplikasi qard dalam perbankan syariah yaitu sebagai pinjaman kepada pengusaha kecil, dimana menurut perhitungan bank akan memberatkan si pengusaha bila diberikan pembiayaan dengan akad jual beli, ijarah atau bagi hasil.

\section{Akad-Akad Dalam Bank Syariah}

Menurut Karim, Adiwarman A. (2007:66), akad-akad dalam bank syariah terdiri dari dua akad, diantaranya:

\section{Akad Tabarru' (akad kebaikan)}

Akad tabarru' (gratuitous countract) adalah segala macam perjanjian yang menyangkut notfor profit (transaksi nirlaba). Pada hakikatnya, akad tabarru' adalah akad melakukan kebaikan yang mengharapkan balasan dari Allah SWT semata. Itu sebabnya akad ini tidak bertujuan untuk mencari keuntungan komersil, tapi akad tabarru' dilakukan dengan tujuan tolong-menolong dalam rangka berbuat kebaikan. Contoh akad-akad tabarru' adalah qard, rahn, hiwalah, wakalah, kafalah, wadi'ah, hibah, wakaf, shadaqah, hadiah dan lain-lain.

Ada tiga bentuk umum akad tabarru', yaitu sebagai berikut:

a. Meminjamkan uang (lending \$)

- Qard merupakan pinjaman yang diberikan tanpa mensyaratkan apapun, selain mengembalikan pinjaman tersebut setelah jangka waktu tertentu;

- Rahn merupakan pinjaman yang diberikan dengan persyaratan suatu jaminan dalam bentuk utang atau jumlah tertentu;

- Hiwalah adalah suatu bentuk pemberian pinjaman uang dengan tujuan untuk mengambil alih piutang dari pihak lain.

b. Meminjamkan Jasa Kita (Lending Yourself)

- Wakalah merupakan peminjaman dalam bentuk jasa, seperti keahlian yang dilakukan atas nama orang lain;

- Wadi'ah merupakan suatu tugas tertentu yang diberikan oleh pihak lain yang dianggap sebagai jasa pemeliharaan;

- Kafalah, yaitu mempersiapkan diri untuk melakukan sesuatu apabila terjadi sesuatu. Hal ini disebut juga wakalah kontinjensi.

c. Memberikan Sesuatu (Giving Something)

- Wakaf merupakan pemberian sesuatu kepada orang lain untuk kepentingan umum dan agama;

- Hibah dan hadiah merupakan pemberian sesuatu secara sukarela kepada orang lain;

- Shadaqah adalah pemberian sesuatu baik dalam bentuk barang maupun jasa tanpa mengharapkan imbalan.

\section{Akad Tijarah (akad bisnis)}

Akad Tijarah/mu'awadah (compensational contract) adalah segala macam perjanjian yang menyangkut for profit transaction. Akad-akad ini dilakukan dengan tujuan mencari keuntungan, karena ini bersifat komersil. Contoh akad tijarah adalah akad-akad investasi, jual-beli, sewa menyewa, dan lain-lain.

Berdasarkan tingkat kepastian dari hasil yang diperolehnya akad tijarah dapat dibagi menjadi dua kelompok besar, yakni:

a. Natural Uncertainty Contract (NUC)

Dalam NUC, pihak-pihak yang bertransaksi saling mencampurkan asetnya (baik real assets maupun financial assets) menjadi satu kesatuan, dan kemudian menanggung risiko bersama-sama untuk mendapatkan keuntungan. Contoh-contoh Natural Uncertainty Contract adalah Musyarakah (wujuh, 'inan, abdan, muwafadhah, mudharabah), Mudharabah, Muzara'ah, dan Musaqah.

b. Natural Certainty Contract (NCC)

Dalam NCC, kedua belah pihak saling mempertukarkan asset yang dimilikinya, karena objek pertukarannya (baik barang maupun jasa) harus ditetapkan di awal akad dengan pasti, baik jumlahny (quantity), mutunya (quality), harganya (price), dan waktu penyerahannya (time of delivery). Contoh Natural Certainty Contract, yaitu akad jual-beli (murabahah, salam, dan istisna') dan akad sewa-menyewa (ijarah dan IMBT).

\section{Bagi Hasil (Reveneu Sharing)}

1. Pengertian Bagi Hasil (Revenue Sharing) 
Dengan lahirnya Bank Islam yang beroperasi berdasarkan sistem bagi hasil sebagai alternatif pengganti bunga bank-bank konvensional merupakan peluang bagi umat Islam untuk memanfaatkan jasa-jasa bank seoptimal mungkin tanpa keraguan adan didasari oleh motivasi keagamaan yang kuat di dalam memobilisasi dana masyarakat untuk pembiayaan pembangunan ekonomi umat. Bank Islam dengan sistem bagi hasilnya sebagai alternatif pengganti dari penerapan sistem bunga ternyata dinilai telah berhasil menghindarkan dampak negatif dari penerapan bunga, diantaranya pembebanan pada nasabah berlebih-lebihan dengan beban bunga bagi nasabah yang tidak mampu membayar pada saat jatuh tempo, timbulnya pemerasan yang kuat terhadap yang lemah, terjadinya kosentrasi kekuatan ekonomi di tangan kelompok elite, para banker dan pemilik modal; kurangnya peluang bagi kekuatan ekonomi lemah untuk mengembangkan potensi usahanya (Sumitro, 2002:6).

Profit-loss sharing berarti keuntungan dan atau kerugian yang mungkin timbul dari kegiatan ekonomi/bisnis ditanggung bersama-sama. Dalam atribut nisbah bagi hasil tidak terdapat suatu fixed and certain return sebagaimana bunga, tetapi dilakukan profit and loss sharing berdasarkan produktifitas nyata dari produk tersebut (Karim, Adiwarman A. : 2001).

Menurut Antonio (2001:137) menyebutkan bahwa prinsip bagi hasil (Revenue sharing) merupakan karakteristik umum dan landasan dasar bagi operasional bank secara keseluruhan. Sedangkan menurut Arbi (2003:215), menjelaskan bahwa bagi hasil adalah suatu perkongsian, di mana terjadi perserikatan dua orang/pihak atau lebih dalam suatu kegiatan usaha atau proyek dimana masingmasing pihak berhak atas segala keuntungan dan bertanggung jawab akan segala kerugian yang terjadi. Berdasarkan prinsip ini, bank Islam berfungsi sebagai mitra, baik dengan penabung maupun dengan pengusaha yang meminjam dana.

Dalam sistem keuangan tanpa bunga (sistem keuangan syariah), yang berupaya dijalankan oleh para penganut prinsip-prinsip Islam, seseorang dapat memperoleh keuntungan dari uang mereka hanya dengan cara tunduk pada risiko yang termasuk dalam skema bagi hasil.
Berdasarkan penjelasan di atas, dapat disimpulkan bahwa sistem bagi hasil adalah pembagian keuntungan atau kerugian yang diperoleh dari pengelolaan suatu proyek dengan cara tunduk pada risiko, secara ekonomis ditanggung bersama-sama dan merupakan landasan dasar bagi operasional bank yang digunakan sebagai alternatif pengganti bunga.

2. Mekanisme Perhitungan Bagi Hasil

Mekanisme perhitungan bagi hasil yang diterapkan di dalam perbankan syariah terdiri dari dua sistem, yaitu profit sharing dan revenue sharing. Profit sharing (bagi untung) yakni bagi hasil yang dihitung dari pendapatan setelah dikurangi biaya-biaya. Dalam sistem profit sharing, berarti yang dibagikan kepada nasabah adalah keuntungan bersih bank. Apabila bank tidak mendapatkan keuntungan (profit), artinya nasabah tidak akan mendapatkan bagi hasil dari investasinya di bank syariah yang bersangkutan.

Sedangkan revenue sharing (bagi hasil) adalah bagi hasil yang dihitung dari pendapatan tanpa dikurangi biaya-biaya. Dengan sistem revenue sharing, maka pada dasarnya nasabah yang menempatkan dananya, misalnya dalam bentuk deposito mudharabah, tetap akan mendapatkan bagi hasil sesuai yang telah disepakati di awal perjanjian. Dalam rangka penghimpunan dana masyarakat dan meningkatkan pendapatan bank syariah, maka perbankan syariah pada umumnya mengaplikasikannya dengan menggunakan sistem profit sharing maupun revenue sharing tergantung kepada kebijakan masing-masing bank untuk memilih salah satu dari sistem yang ada. Bank-bank syariah yang ada di Indonesia saat ini semuanya menggunakan perhitungan bagi hasil atas dasar revenue sharing untuk mendistribusikan bagi hasil kepada para pemilik dana (deposan).

3. Metode Penentuan Nisbah Bagi Hasil

Bank syariah menerapkan Nisbah Bagi Hasil terhadap produk-produk pembiayaan yang berbasis Natural Uncertainty Contract (NUC), yakni akad bisnis yang tidak memberikan kepastian pendapatan (return), baik dari segi jumlah (amount) maupun waktu (timing), seperti mudharabah dan musyarakah.

Menurut Karim, (2007:287), terdapat tiga metode penentuan nisbah bagi hasil pembiayaan 
dalam perbankan syariah :

a. Penentuan nisbah bagi hasil keuntungan

b. Penentuan nisbah bagi hasil pendapatan

c. Penentuan nisbah bagi hasil penjualan

Selain penentuan nisbah bagi hasil untuk pembiayaan, bank juga dapat mengalokasikan penghasilannya melalui simpanan dengan tahap-tahap sebagai berikut (Arifin, 2006:57):

a. Bank menetapkan jumlah relatif masingmasing dana simpanan yang berhak atas bagi hasil usaha bank menurut tipenya dengan cara membagi setiap tipe dana-dana dengan seluruh jumlah dana yang ada pada bank yang dikalikan $100 \%$.

b. Bank menetapkan jumlah pendapatan bagi hasil untuk masing-masing tipe dengan cara mengalikan persentase dengan masing-masing dana simpanan.

c. Bank menetapkan porsi bagi hasil untuk masing-masing tipe dana simpanan sesuai dengan nisbah yang diperjanjikan.

d. Bank harus menghitung jumlah relatif biaya operasional terhadap volume dana.

e. Bank mendistribusikan bagi hasil setiap pemegang rekening menurut tipe simpanannya.

\section{Menghitung Bagi Hasil}

Nisbah bagi hasil adalah istilah yang digunakan dalam bank syariah yaitu proporsi bagi hasil antara nasabah dan bank syariah. Misalnya, suatu tabungan atau deposito mudharabah dengan nisbah bagi hasil $65: 35$ berarti nasabah tersebut akan mendapatkan 65\% dan bank syariah 35\% dari return yang diperoleh bank syariah dari pengelolaan dana yang dilakukan.

\section{Pengetahuan}

\section{Pengertian Pengetahuan}

Pengetahuan merupakan segala sesuatu yang ada dalam pikiran seseorang setelah dilakukan pengindraan terhadap suatu objek tertentu. Menurut Notoatmodjo (2003:121) menyatakan bahwa Pengetahuan merupakan hasil "Tahu" dan ini terjadi setelah orang melakukan pengindraan terhadap suatu objek tertentu. Pengindraan terjadi melalui pancaindra manusia yakni: penglihatan, pendengaran, penciuman, rasa dan raba. Sebagian besar pengetahuan manusia diperoleh melalui mata dan telinga.

Pengetahun yang cukup didalam domain kognitif mempunyai 6 tingkatan, yaitu (Notoatmodjo, 2003) :

\section{a. Tahu (Know)}

Tahu diartikan sebagai mengingat suatu materi yang telah pelajari sebelumnya. Termasuk ke dalam pengetahuan tingkat ini adalah mengingat kembali (recall) sesuatu yang spesifik dari seluruh bahan yang dipelajari atau rangsangan yang telah diterima. Oleh sebab itu tahu ini merupakan tingkat pengetahuan yang paling rendah. Kata kerja untuk mengukur bahwa orang tahu tentang apa yang dipelajari antara lain menyebutkan, menguraikan, mendefinisikan, menyatakan dan sebagainya.

b. Memahami (Comprehention)

Memahami diartikan sebagai suatu kemampuan untuk menjelaskan secara benar tentang objek yang diketahui, dan dapat menginterpretasikan materi tersebut secara benar. Orang yang telah paham terhadap objek atau materi harus dapat menjelaskan, menyebutkan contoh, menyimpulkan, meramalkan, dan sebagainya terhadap objek yang dipelajari.

\section{c. Aplikasi (Application)}

Aplikasi diartikan sebagai kemampuan untuk menggunakan materi yang telah dipelajari pada situasi atau kondisi real (sebenarnya). Aplikasi disini dapat diartikan sebagai aplikasi atau penggunaan hukum-hukum, rumus, metode, prinsip dan sebagainya dalam konteks atau situasi yang lain.

\section{d. Analisis (Analysis)}

Analisis adalah kemampuan untuk menjabarkan materi atau suatu objek ke dalam komponenkomponen, tetapi masih di dalam satu struktur organisasi, dan masih ada kaitannya satu sama lain. Kemampuan analisis ini dapat dilihat dari penggunaan kata kerja, seperti dapat menggambarkan (membuat bagan), membedakan, memisahkan, mengelompokkan, dan sebagainya.

e. Sintesis (Synthesis)

Sintesis menunjuk kepada suatu kemampuan untuk meletakkan atau menghubungkan bagianbagian di dalam suatu bentuk keseluruhan yang baru. Dengan kata lain sintesis adalah suatu kemampuan untuk menyusun formulasi baru dari 
formulasi-formulasi yang ada.

f. Evaluasi (Evaluation)

Evaluasi ini berkaitan dengan kemampuan untuk melakukan justifikasi atau penilaian terhadap suatu materi atau objek. Penilaian-penilaian itu didasarkan pada suatu kreteria yang ditentukan sendiri, atau menggunakan kriteria-kriteria yang telah ada.

2. Faktor yang Mempengaruhi Tingkat Pengetahuan

a. Faktor Internal

- Pendidikan berarti bimbingan yang diberikan seseorang terhadap perkembangan orang lain menuju kearah cita-cita tertentu yang menentukan manusia untuk berbuat dan mengisi kehidupan untuk mencapai keselamatan dan kebahagiaan. Pendidikan diperlukan untuk mendapat informasi misalnya hal-hal yang menunjang kesehatan sehingga dapat meningkatkan kualitas hidup. Menurut YB Mantra yang dikutip Notoadmojo (2003) ,pendidikan dapat mempengaruhi seseorang termasuk juga perilaku seseorang akan pola hidup terutama dalam memotivasi untuk sikap berperan serta dalam pembangunan (Nursalam,2003) pada umumnya makin tinggi pendidikan seseorang makin mudah menerima informasi.

- Pekerjaan, menurut Thomas yang dikutip oleh Nursalam (2003), pekerjaan adalah keburukan yang harus dilakukan terutama untuk menunjang kehidupannya dan kehidupan keluarga. Pekerjaan bukanlah sumber kesenangan ,tetapi lebih banyak merupakan cara mencari nafkah yang membosankan ,berulang dan banyak tantangan. Sedangkan bekerja umumnya merupakan kegiatan yang menyita waktu. Bekerja bagi ibu-ibu akan mempunyai pengaruh terhadap kehidupan keluarga.

- Umur, menurut Elisabeth BH yang dikutip Nursalam (2003), usia adalah umur individu yang terhitung mulai saat dilahirkan sampai berulang tahun.Sedangkan menurut Huclok (1998) semakin cukup umur,tingkat kematangan dan kekuatan seseorang akan lebih matang dalam berfikir dan bekerja. Dari segi kepercayaan masyarakat seseorang yang lebih dewasa dipercaya dari orang yang belum ting- gi kedewasaannya. Hal ini akan sebagai dari pengalaman dan kematangan jiwa.

b. Faktor Eksternal

- Faktor Lingkungan, menurut Ann. Mariner yang dikutip dari Nursalam (3 lingkungan) merupakan seluruh kondisi yang ada disekitar manusia dan pengaruhnya yang dapat mempengaruhi perkembangan dan perilaku orang atau kelompok.

- Sosial Budaya, sistem sosial budaya yang ada pada masyarakat dapat mempengaruhi dari sikap dalam menerima informasi.

3. Kriteria Tingkat Pengetahuan

Menurut Arikunto (2006) pengetahuan seseorang dapat diketahui dan diinterpretasikan dengan skala yang bersifat kualitatif, yaitu:

a. Baik: Hasil presentase $76 \%-100 \%$

b. Cukup: Hasil presentase $56 \%-75 \%$

c. Kurang: Hasil presentase $>56 \%$

\section{METODE PENELITIAN}

\section{Populasi Dan Sampel}

Populasi adalah keseluruhan objek yang mempunyai satu karakteristik yang sama (Purwanto, 2008:85). Menurut Sugiyono (2007:80), Populasi adalah wilayah generalisasi yang terdiri atas obyek/subyek yang mempunyai kualitas dan karakteristik tertentu yang ditetapkan oleh peneliti untuk dipelajari dan kemudian ditarik kesimpulannya. Populasi dalam penelitian ini adalah seluruh masyarakat umum dan masyarakat santri yang ada di Kemukiman Bandar Baru Kecamatan Banda Baro-Aceh Utara. Jumlah populasi masyarakat umum adalah 920 orang dan masyarakat santri adalah 100 orang yang berumur 15 Tahun ke atas.

Menentukan ukuran sampel dilihat dari jumlah anggota sampel yang sering dinyatakan dengan ukuran sampel. Menurut Arikunto (2006:134) adalah apabila subyek kurang dari 100 lebih baik diambil semua sehingga penelitiannya termasuk penelitian populasi, selanjutnya bila subyeknya lebih dari 100 dapat diambil 10\%-15\% atau 20\%-25\%. Dalam penelitian ini untuk masyarakat umum yang dijadikan sampel sebesar $10 \%$ dari jumlah populasi sebanyak 920 orang dengan teknik yang digunakan untuk pengambilan sampel adalah 
teknik cluster sampling. Sedangkan masyarakat santri jumlah populasinya sebanyak 100 orang dan semuanya dijadikan sebagai sampel, diantaranya 48 orang laki-laki dan 52 orang perempuan. Berikut pengambilan sampel dari populasi dengan memakai rumus slovin (Bungin, 2005):

$$
n=\frac{N}{N(d)^{2}+1}
$$

Dimana :

$\mathrm{n}=$ Jumlah Sampel yang dicari

$\mathrm{N}=$ Jumlah populasi

$\mathrm{d}=$ Nilai Presisi / tingkat kesalahan (10\%)

Maka perhitungan sampelnya yaitu berdasarkan total dari Tabel 1 di bawah:

$$
\begin{aligned}
& n=\frac{N}{N(d)^{2}+1} \\
& n=\frac{920}{920(0,1)^{2}+1}=\frac{920}{9,2}=100 \text { orang }
\end{aligned}
$$

Jmlah sampel yang diambil berdasarkan desa secara proporsional probability dan jenis kelamin ditentukan kembali dengan perhitungan sebagai berikut:

Berdasarkan Tabel 1 dan 2 di atas, dapat dilihat bahwa secara keseluruhan jumlah sampel masyarakat umum yang berjenis laki-laki sebanyak 47 orang dan untuk perempuan sebanyak 53 orang. Sedangkan sampel yang ditentukan berdasarkan desa yaitu untuk Desa Cot Jabet sebanyak 7 orang laki-laki dan 8 orang perempuan, Desa Ulee Nyeue sebanyak 11 orang laki-laki dan 14 orang perempuan, Desa Paya Uleue dan Alue Keurinyai masing-masing sebanyak 9 orang lakilaki dan 9 orang perempuan dan Desa Jamuan sebanyak 11 orang laki-laki dan 13 orang perempuan.

\section{Teknik Pengumpulan Data}

Menurut Nasution (2003:113), wawancara atau interview adalah suatu bentuk komunikasi verbal atau semacam percakapan yang bertujuan memperoleh interview. Dalam wawancara, pertanyaan dan jawaban diberikan secara verbal. Biasanya komunikasi ini dilakukan dalam keadaan saling berhadapan, namun komunikasi dapat juga dilaksanakan melalui telepon. Wawancara yang digunakan dalam penelitian ini adalah wawancara secara terbuka. Wawancara tersebut merupakan wawancara yang berstruktur dimana peneliti tidak membuka kebebasan bagi responden untuk berbicara sesuka hatinya. Pada saat melakukan wawancara, peneliti dapat menggunakan daftar

\begin{tabular}{|c|c|c|c|c|c|c|c|c|c|c|}
\hline \multirow{3}{*}{$\begin{array}{c}\text { Kampung/Desa/ } \\
\text { Kelurahan }\end{array}$} & \multicolumn{10}{|c|}{ Jumlah Masyarakat berdasarkan Umur (Tahun) dan Jenis Kelamin } \\
\hline & \multicolumn{5}{|c|}{ Laki-Laki } & \multicolumn{5}{|c|}{ Perempuan } \\
\hline & $15-24$ & $25-34$ & $35-44$ & $45-54$ & $55^{*}$ & $15-24$ & $25-34$ & $35-44$ & $45-54$ & $55^{*}$ \\
\hline Cot Jabet & 14 & 15 & 18 & 14 & 6 & 15 & 13 & 15 & 14 & 12 \\
\hline Ulee Nyeue & 20 & 31 & 26 & 17 & 10 & 20 & 30 & 34 & 25 & 20 \\
\hline Paya Uleue & 10 & 26 & 20 & 14 & 10 & 12 & 18 & 25 & 16 & 12 \\
\hline Alue Keurinyai & 13 & 19 & 23 & 15 & 8 & 15 & 24 & 31 & 10 & 8 \\
\hline Jamuan & 20 & 20 & 23 & 26 & 15 & 25 & 24 & 25 & 20 & 20 \\
\hline
\end{tabular}

Tabel 1

Jumlah Masyarakat Umum berdasarkan Umur dan Jenis Kelamin

Sumber : Kantor Camat Banda Baro, 2016

Tabel 2

Penentuan Sampel Berdasarkan Jenis Kelamin Dan Desa Dari Masyarakat Umum

\begin{tabular}{llcccc}
\hline \multirow{2}{*}{ No } & \multicolumn{1}{c}{$\begin{array}{c}\text { Kampung/Desa/ } \\
\text { Kelurahan }\end{array}$} & $\mathbf{L}$ & $\mathbf{P}$ & \multicolumn{2}{c}{ Sampel } \\
\cline { 3 - 6 } & & $67 \times 10,87 \%$ & $69 \times 10,87 \%$ & $\mathbf{L}$ & $\mathbf{P}$ \\
\hline 1 & Cot Jabet & $104 \times 10,87 \%$ & $129 \times 10,87 \%$ & 11 & 8 \\
\hline 2 & Ulee Nyeue & $80 \times 10,87 \%$ & $83 \times 10,87 \%$ & 9 & 9 \\
\hline 3 & Paya Uleue & $78 \times 10,87 \%$ & $88 \times 10,87 \%$ & 9 & 9 \\
\hline 4 & Alue Keurinyai & $104 \times 10,87 \%$ & $118 \times 10,87 \%$ & 11 & 13 \\
\hline 5 & Jamuan & 435 & 485 & 47 & 53 \\
\hline
\end{tabular}


pertanyaan yang telah tersusun secara sistematis atau mungkin menghafalnya di luar kepala agar percakapan menjadi lancar dan wajar sehingga responden/informan dapat memberikan jawabannya dengan singkat, padat dan jelas. Selain itu, dalam penelitian ini juga digunakan angket (kuesioner), yaitu suatu daftar pertanyaan mengenai sesuatu masalah atau bidang yang akan diteliti serta suatu masalah yang akan diwawancarai (Narbuko, Cholid dan Abu Achmadi, 2004:76).

\section{Metode Analisa Data}

Analisis data yang digunakan merupakan statistik deskriptif yaitu untuk mengukur data yang diwakili oleh mean (rata-rata hitung), median dan modus, sedangkan dispersi data yang digunakan berupa deviasi rata-rata dan standar deviasi (Anonymous, 2001:39), dengan alasan untuk mengetahui seberapa paham masyarakat umum dan masyarakat santri terhadap bank syariah.

\section{HASIL PENELITIAN}

\section{Penilaian Pengetahuan Masyarakat Umum terhadap Bank Syariah}

Pengetahuan merupakan Suatu proses keingintahuan masyarakat umum dan masyarakat santri terhadap bank syariah (Studi kasus Kemukiman Bandar Baru Kecamatan Banda Baro-Aceh Utara). Pengetahuan seseorang dapat timbul melalui membaca Koran, Media Cetak, Media Elektronik, dan lainnya tentang Bank Syariah baik secara umum maupun secara khusus. Berikut ini penilaian pengetahuan masyarakat umum terhadap bank syariah berdasarkan kuesioner yang telah di sebar untuk masing-masing desa.

Diketahui bahwa pada uraian pertama jawaban masyarakat umum yang sangat tahu dan tahu bahwa bank syariah merupakan bank yang menjalankan kegiatannya berdasarkan prinsip syariah sebanyak $47 \%$, sedangkan yang menjawab kurang tahu sebanyak 38\% dan sisanya sebanyak 15\% menjawab tidak tahu dan sangat tidak tahu. Dengan demikian, mayoritas responden masyarakat umum mengetahui tentang Bank Syariah dengan skor nilai rata-rata 3,56 atau dibulatkan menjadi 4. Selanjutnya, pada uraian kedua diketahui bahwa sekitar 54\% menjawab sangat tahu dan tahu ter- hadap perbedaan antara bank syariah dan bank konvensional, sedangkan yang menjawab kurang tahu sebanyak $20 \%$ dan sisanya yang menjawab tidak tahu dan sangat tidak tahu sebanyak $26 \%$. Nilai rata-rata yang diperoleh dari pertanyaan tersebut adalah 3,60, artinya responden mengetahui tentang perbedaan bank syariah dengan bank konvensional.

Selanjutnya, pada uraian ketiga diketahui bahwa sekitar $46 \%$ yang menjawab sangat tahu dan tahu tentang bagi hasil, sedangkan yang menjawab kurang tahu sebanyak $37 \%$ dan sisanya menjawab tidak tahu dan sangat tidak tahu sebanyak 17\%. Dari pertanyaan ketiga tersebut rata-rata responden kurang tahu terhadap bagi hasil dengan skor nilai rata-rata yang diperoleh sebesar 3,38. Pada uraian keempat diketahui bahwa sekitar 33\% yang sangat tahu dan tahuterhadap perbedaan antara bagi hasil dan bunga, sedangkan yang menjawab kurang tahu sebanyak 34\% dan sisanya menjawab tidak tahu dan sangat tidak tahu sekitar $33 \%$. Nilai rata-rata yang diperoleh dari pertanyaan keempat tersebut adalah 3,02. Artinya mayoritas responden kurang tahu terhadap perbedaan bunga dan bagi hasil.

Berdasarkan penilaian pengetahuan masyarakt umum tersebut, dapat disimpulkan bahwa secara keseluruhan mayoritas responden masyarakat umum mengetahui tentang bank syariah dengan nilai rata-rata keseluruhannya sebesar 3,39.

Tabulasi silang berdasarkan jenis kelamin dan desa yang dinilai sangat tahu, tahu, kurang tahu, tidak tahu dan sangat tidak tahu dari pengetahuan Masyarakat Umum terhadap Bank Syariah seperti yang terlihat pada Tabel 4, dapat diketahui bahwa pengetahuan masyarakat umum berdasarkan jenis kelamin yaitu responden yang berjenis kelamin laki-laki dan perempuan mayoritasnya mengetahui tentang bank syariah, dengan nilai rata-rata yang diperoleh sebesar 3,32 responden yang berjenis kelamin laki-laki dan 3,62 dari responden yang berjenis kelamin perempuan.

Selanjutnya, berdasarkan tabulasi silang Tabel 5, berdasarkan desa yang ada dikemukiman Bandar Baru yaitu desa Cot Jabet mayoritas masyarakat mengetahui tentang bank syariah. sedangkan Desa Ulee Nyeue, Desa Paya Uleue, Desa Alue Keurinyai dan Jamuan, mayoritas 
Tabel 3

Penilaian Pengetahuan Responden (Masyarakat Umum) Terhadap Bank Syariah

\begin{tabular}{|c|c|c|c|c|c|c|c|}
\hline \multirow{2}{*}{ NO } & \multirow{2}{*}{ Item Pertanyaan } & \multicolumn{5}{|c|}{ Persepsi (\%) } & \\
\hline & & ST & $\mathbf{T}$ & KT & TT & STT & \\
\hline 1 & $\begin{array}{l}\text { Apa yang Bapak/lbu/Tgk/Saudara (i) ketahui ten- } \\
\text { tang Bank Syariah? }\end{array}$ & 25 & 22 & 38 & 14 & 1 & 3.56 \\
\hline 2 & $\begin{array}{l}\text { Menurut Bapak/lbu/Saudara (i) apa yang membe- } \\
\text { dakan bank syariah dan bank konvensional? }\end{array}$ & 37 & 17 & 20 & 21 & 5 & 3.60 \\
\hline 3 & $\begin{array}{l}\text { Dalam perbankan syariah pembagian keuntungan- } \\
\text { nya dinamakan bagi hasil. Apa yang Bapak/lbu/ } \\
\text { Saudara (i) ketahui tentang bagi hasil? }\end{array}$ & 14 & 32 & 37 & 12 & 5 & 3.38 \\
\hline 4 & $\begin{array}{l}\text { Menurut Bapak/lbu/Tgk/Saudara (i) apa perbedaan } \\
\text { antara bunga dan bagi hasil? }\end{array}$ & 14 & 19 & 34 & 21 & 12 & 3.02 \\
\hline \multicolumn{7}{|c|}{ Nilai Rata-Rata Keseluruhan } & 3.39 \\
\hline
\end{tabular}

Sumber : Data Primer, Tahun 2016 (diolah)

Tabel 4

Tabulasi Silang Berdasarkan Jenis Kelamin Pada Penilaian Pengetahuan Masyarakat Umum

\begin{tabular}{|c|c|c|c|c|c|c|c|}
\hline \multirow{2}{*}{ No } & \multirow{2}{*}{ Jenis Kelamin } & \multicolumn{5}{|c|}{ Penilaian Jawaban } & \\
\hline & & ST & $\mathbf{T}$ & CT & TT & STT & \\
\hline 1 & Laki-Laki & 5 & 17 & 15 & 9 & 0 & 3.32 \\
\hline 2 & Perempuan & 9 & 24 & 13 & 6 & 1 & 3.62 \\
\hline \multicolumn{7}{|c|}{ Nilai Rata-rata Keseluruhan } & 3.47 \\
\hline
\end{tabular}

Sumber : Data Primer, Tahun 2016 (diolah)

Tabel 5

Tabulasi Silang Berdasarkan Desa Pada Penilaian Pengetahuan Masyarakat Umum

\begin{tabular}{|c|c|c|c|c|c|c|c|}
\hline \multirow{2}{*}{ No } & \multirow{2}{*}{ Desa } & \multicolumn{5}{|c|}{ Penilaian Jawaban } & \\
\hline & & ST & $\mathbf{T}$ & CT & TT & STT & \\
\hline 1 & Cot Jabet & 0 & 9 & 3 & 2 & 1 & 3.33 \\
\hline 2 & Ulee Nyeue & 4 & 9 & 8 & 4 & 0 & 3.52 \\
\hline 3 & Paya Uleue & 2 & 6 & 10 & 0 & 0 & 3.56 \\
\hline 4 & Alue Keurinyai & 2 & 11 & 3 & 2 & 0 & 3.72 \\
\hline 5 & Jamuan & 6 & 6 & 5 & 7 & 0 & 4.46 \\
\hline \multicolumn{7}{|c|}{ Nilai Rata-rata Keseluruhan } & 3.52 \\
\hline
\end{tabular}

Sumber : Data Primer diolah

Tabel 6

Penilaian Pengetahuan Responden (Masyarakat Santri) Terhadap Bank Syariah

\begin{tabular}{|c|c|c|c|c|c|c|c|}
\hline \multirow[b]{2}{*}{ NO } & \multirow[b]{2}{*}{ Item Pertanyaan } & \multicolumn{5}{|c|}{ Persepsi (\%) } & \\
\hline & & ST & $\mathbf{T}$ & CT & TT & STT & \\
\hline 1 & $\begin{array}{l}\text { Apa yang Bapak/lbu/Tgk/Saudara (i) ketahui tentang } \\
\text { Bank Syariah? }\end{array}$ & 14 & 33 & 48 & 4 & 1 & 3.55 \\
\hline 2 & $\begin{array}{l}\text { Menurut Bapak/lbu/Saudara (i) apa yang membeda- } \\
\text { kan bank syariah dan bank konvensional? }\end{array}$ & 25 & 19 & 49 & 7 & 0 & 3.62 \\
\hline 3 & $\begin{array}{l}\text { Dalam perbankan syariah pembagian keuntungan- } \\
\text { nya dinamakan bagi hasil. Apa yang Bapak/lbu/ } \\
\text { Saudara (i) ketahui tentang bagi hasil? }\end{array}$ & 4 & 10 & 56 & 23 & 7 & 2.81 \\
\hline 4 & $\begin{array}{l}\text { Menurut Bapak/lbu/Tgk/Saudara (i) apa perbedaan } \\
\text { antara bunga dan bagi hasil? }\end{array}$ & 1 & 7 & 55 & 16 & 21 & 2.51 \\
\hline
\end{tabular}

Sumber : Data Primer, Tahun 2016 (diolah) 
masyarakat tahu terhadap bank syariah. Dari kelima desa tersebut yang memperoleh nilai rata-rata tertinggi adalah Desa Jamuan yaitu sebesar 4,46 dari pada Desa-desa lainnya. Artinya, masyarakat di Desa tersebut mengetahui bahwa bank syariah dijalankan sesuai dengan syariah islam, sesuai dengan hukum-hukum islam dan jauh dari pada riba.

\section{Penilaian Pengetahuan Masyarakat Santri terhadap Bank Syariah}

Berikut ini penilaian pengetahuan masyarakat santri terhadap bank syariah berdasarkan kuesioner yang telah di sebar untuk masing-masing tempat pengajian.

Berdasarkan Table 6 diketahui bahwa pada uraian pertama jawaban masyarakat santri yang sangat tahu dan tahu bahwa bank syariah merupakan bank yang menjalankan kegiatannya berdasarkan prinsip syariah sebanyak $47 \%$, sedangkan yang menjawab kurang tahu sebanyak 48\% dan sisanya sebanyak 5\% menjawab tidak tahu dan sangat tidak tahu. Dengan demikian, mayoritas responden masyarakat santri kurang tahu terhadap Bank Syariah dengan skor nilai rata-rata 3,55.

Selanjutnya. pada uraian kedua diketahui bahwa sekitar 44\% menjawab sangat tahu dan tahu terhadap perbedaan antara bank syariah dan bank konvensional, sedangkan yang menjawab kurang tahu sebanyak $49 \%$ dan sisanya yang menjawab tidak tahu $7 \%$ dan sangat tidak tahu sebanyak $0 \%$. Nilai rata-rata yang diperoleh dari pertanyaan tersebut adalah 3,62, artinya responden mengetahui tentang perbedaan bank syariah dengan bank konvensional. Selanjutnya, pada uraian ketiga diketahui bahwa sekitar 14\% yang menjawab sangat tahu dan tahu tentang bagi hasil, sedangkan yang menjawab kurang tahu sebanyak 56\% dan sisanya menjawab tidak tahu dan sangat tidak tahu sebanyak 30\%. Dari pertanyaan ketiga tersebut rata-rata responden kurang tahu terhadap bagi hasil dengan skor nilai rata-rata yang diperoleh sebesar 2,81.

Pada uraian keempat diketahui bahwa sekitar $8 \%$ yang sangat tahu dan tahu terhadap perbedaan antara bagi hasil dan bunga, sedangkan yang menjawab kurang tahu sebanyak 55\% dan sisanya menjawab tidak tahu dan sangat tidak tahu sekitar
$37 \%$. Nilai rata-rata yang diperoleh dari pertanyaan keempat tersebut adalah 2,15. Artinya mayoritas responden masyarakat santri sangat tidak tahu tentang perbedaan antara bunga dan bagi hasil. Dikarenakan mereka masih ragu dengan kehalalan kedua sistem tersebut sehingga sebagian dari mereka banyak yang tidak memberi tanggapan terhadap perbedaan bunga dan bagi hasil.

Berdasarkan penilaian pengetahuan masyarakat santri tersebut, dapat disimpulkan bahwa secara keseluruhan mayoritas responden masyarakat santri kurang tahu tentang bank syariah dengan nilai rata-rata keseluruhannya sebesar 3,12.

Tabulasi silang berdasarkan jenis kelamin dan Dayah/Balai Pengajian yang dinilai sangat tahu, tahu, kurang tahu, tidak tahu dan sangat tidak tahu dari pengetahuan Masyarakat Santri terhadap Bank Syariah adalah seperti terlihat pada Tabel 7, diketahui bahwa pengetahuan masyarakat santri berdasarkan jenis kelamin yaitu responden yang berjenis kelamin laki-laki dan perempuan cukup tahu terhadap bank syariah dengan skor nilainya 3,29.

Dayah/Balai Pengajian yang ada dikemukiman Bandar Baru yaitu responden masyarakat santri dari Dayah Terpadu Darul Ma'rifah dan Balai Pengajian Babussalam Al-Aziziyah rata-rata cukup tahu terhadap bank syariah sebesar 3,33 dikarenakan bank syariah dijalankan berdasarkan penjelasan Al-Quran dan Al-Hadits, bank syariah tidak mengandung riba ataupun bank syariah merupakan bank digunakan masyarakat untuk menyimpan uangnya agar tidak hilang. Disamping itu, masyarakat santri hanya mengetahui tentang bank syariah melalui Guru-gurunya, Televisi dan Surat Kabar seperti Koran. Sehingga mereka mendapatkan ilmu pengetahuan mengenai bank syariah sebatas yang mereka ketahui.

\section{Penilaian Pengetahuan Masyarakat Umum dan Masyarakat Santri Terhadap Bank Sya- riah Dalam Penerapan Prinsip Syariah}

Berikut ini penilaian pengetahuan masyarakat umum dan masyarakat santri terhadap bank syariah berdasarkan kuesioner yang telah di sebar untuk masing-masing Desa dan Da.yah/Balai Pengajian.

Pertanyaan kedua dari kuesioner, hasil wawancara yang diperoleh dari responden yaitu 
Tabel 7

Tabulasi Silang Berdasarkan Jenis Kelamin Pada Penilaian Pengetahuan Masyarakat Santri

\begin{tabular}{|c|c|c|c|c|c|c|c|}
\hline \multirow{2}{*}{ No } & \multirow{2}{*}{ Jenis Kelamin } & \multicolumn{5}{|c|}{ Penilaian Jawaban } & \\
\hline & & ST & $\mathbf{T}$ & CT & TT & STT & \\
\hline 1 & Laki-Laki & 0 & 19 & 24 & 5 & 0 & 3.29 \\
\hline 2 & Perempuan & 2 & 16 & 29 & 5 & 0 & 3.29 \\
\hline \multicolumn{7}{|c|}{ Nilai Rata-rata Keseluruhan } & 3.29 \\
\hline
\end{tabular}

Sumber : Data Primer, Tahun 2016 (diolah)

Tabel 8

Tabulasi Silang Berdasarkan Dayah/Balai Pengajian Pada Penilaian Pengetahuan Masyarakat Santri

\begin{tabular}{cccccccc}
\hline \multirow{2}{*}{ No } & Dayah/Balai & \multicolumn{7}{c}{ Penilaian Jawaban } & \\
\cline { 2 - 7 } 1 & Dayah Terpadu Darul & SP & P & CP & TP & STP & \\
\hline 2 & $\begin{array}{c}\text { Balai Pengajian Ba- } \\
\text { bussalam Al-Aziziyah }\end{array}$ & 0 & 11 & 19 & 2 & 0 & 3.38 \\
\hline \multicolumn{7}{c}{ Nilai Rata-rata Keseluruhan } \\
\hline
\end{tabular}

Sumber : Data Primer, Tahun 2016 (diolah)

Tabel 9

Penilaian Pengetahuan Responden (Masyarakat Umum dan Masyarakat Santri) Terhadap Bank Syariah Dalam Penerapan Prinsip Syariah

\begin{tabular}{|c|c|c|c|c|c|}
\hline \multirow{3}{*}{ NO } & \multirow{3}{*}{ Item Pertanyaan } & \multicolumn{4}{|c|}{ Jawaban Responden } \\
\hline & & \multicolumn{2}{|c|}{$\begin{array}{l}\text { Masyarakat } \\
\text { Umum }\end{array}$} & \multicolumn{2}{|c|}{$\begin{array}{c}\text { Masyarakat } \\
\text { Santri }\end{array}$} \\
\hline & & $f$ & $\%$ & $F$ & $\%$ \\
\hline \multirow{3}{*}{1} & $\begin{array}{l}\text { Sebagian orang berpendapat bahwa bank syariah saat ini da- } \\
\text { lam melaksanakan kegiatannya telah menerapkan prinsip syari- } \\
\text { ah, sementara sebagian lainnya berpendapat bahwa bank sya- } \\
\text { riah sama dengan bank konvensional. Dari kedua pandangan } \\
\text { tersebut, yang mana lebih cocok dengan pandangan Bapak/ } \\
\text { lbu/Tgk/ Sdr (i)? }\end{array}$ & & & & \\
\hline & $\begin{array}{l}\text { a. Bank Syariah melaksanakan kegiatannya berdasarkan prin- } \\
\text { sip syariah sehingga apa yang dilaksanakan saat ini sudah } \\
\text { bebas riba. }\end{array}$ & 64 & 64.0 & 42 & 42.0 \\
\hline & $\begin{array}{l}\text { b. Bank Syariah dalam melaksanakan kegiatannya sama } \\
\text { dengan bank konvensional dan masih mengandung unsur } \\
\text { bunga dan riba. }\end{array}$ & 36 & 36.0 & 58 & 58.0 \\
\hline
\end{tabular}

Sumber : Data Primer, Tahun 2016 (diolah)

Tabel 10

Hasil Uji Beda Pengetahuan Masyarakat Umum dan Masyarakat Santri Terhadap Bank Syariah

\begin{tabular}{lr}
\hline \multicolumn{1}{c}{ Keterangan } & Nilai \\
\hline Mean Masyarakat Umum & 3,39 \\
\hline Mean Masyarakat Santri & 3,12 \\
\hline Sig. (2-tailed) & 0,032 \\
\hline
\end{tabular}

Sumber : Data Primer, Tahun 2016 (diolah) 
dari masyarakat umum yang menjawab bahwa bank syariah saat ini dalam melaksanakan kegiatannya telah menerapkan prinsip syariah sehingga apa yang dilaksanakan saat ini sudah bebas riba sebanyak 64 orang atau $64 \%$ dan yang menjawab bahwa bank syariah dalam melaksanakan kegiatannya sama dengan bank konvensional dan masih mengandung unsur bunga dan riba sebanyak 36 orang atau $36 \%$. Sedangkan dari masyarakat santri yang menjawab bahwa bank syariah saat ini dalam melaksanakan kegiatannya telah menerapkan prinsip syariah sehingga apa yang dilaksanakan saat ini sudah bebas riba sebanyak 42 orang atau $42 \%$ dan yang menjawab bahwa bank syariah dalam melaksanakan kegiatannya sama dengan bank konvensional dan masih mengandung unsur bunga dan riba sebanyak 58 orang atau $58 \%$. Oleh karena itu, masyarakat umum lebih mengetahui tentang bank syariah dari pada masyarakat santri.

\section{Pengujian Hipotesis Perbedaan Pengetahuan antara Masyarakat Umum Dan Masyarakat Santri}

Pengujian ini dilakukan untuk mengetahui ada tidaknya perbedaan yang signifikan antara pengetahuan masyarakat umum dan masyarakat santri. Alat uji yang digunakan adalah uji beda rata-rata dengan derajat signifikan $5 \%$. Berdasarkan teori yang telah dikemukakan sebelumnya, maka peneliti menetapkan hipotesis penelitian untuk pengujian perbedaan pengetahuan masyarakat umum dan masyarakat santri sebagai berikut:

$\mathrm{H}_{0}=0$, Tidak terdapat perbedaan antara pengetahuan masyarakat umum dan masyarakat santri terhadap Bank Syariah (Studi Kasus Kemukiman Bandar Baru Kecamatan Banda BaroAceh Utara).

$\mathrm{H}_{1} \neq 0$, Ada perbedaan antara pengetahuan masyarakat umum dan masyarakat santri terhadap Bank Syariah (Studi Kasus Kemukiman Bandar Baru Kecamatan Banda Baro-Aceh Utara).

Apabila t-hitung $<\mathrm{t}$-tabel maka $\mathrm{H}_{0}$ diterima/ $\mathrm{H}_{1}$ ditolak dan apabila t-hitung $>\mathrm{t}$-tabel maka $\mathrm{H}_{0}$ ditolak/ $\mathrm{H}_{1}$ diterima (Nugroho, 2011:51). Oleh karena itu, hasil perhitungan dengan menggunakan Program SPSS versi 17.0 diperoleh sebagaimana tabel berikut ini:
Uji beda rata-rata antara pengetahuan masyarakat umum dengan masyarakat santri terhadap bank syariah. Nilai rata-rata pengetahuan masyarakat umum adalah 3,39 (Std. Deviation $=0,879)$, sedangkan nilai rata-rata pengetahuan masyarakat santri adalah 3,12 (Std. Deviation = 0,610). Selisih antara nilai rata-rata pengetahuan masyarakat umum berbeda dengan masyarakat santri yaitu sebesar 0,268. Dengan kata lain, rata-rata masyarakat umum lebih tinggi dari pada rata-rata masyarakat santri. Hal ini menunjukkan bahwa masyarakat umum lebih mengetahui tentang bank syariah dibandikan masyarakat santri. Dikarenakan sebagian masyarakat umum telah memiliki ilmu tentang muamalah atau telah menjadi nasabah bank syariah dan sebagainya, sehingga pengetahuan mereka lebih luas tentang bank syariah.

Perbedaan pengetahuan masyarakat umum dan masyarakat santri pada penelitian ini terjadi pada tingkat signifikan sebesar 0,032 (3,2\%). Sementara itu, uji signifikan yang dilakukan adalah pada tingkat signifikan $5 \%$. Oleh karena itu, hasil penelitian tersebut menunjukkan adanya perbedaan pengetahuan secara signifikan antara masyarakat umum dengan masyarakat santri terhadap bank syariah. Ini terlihat dari nilai sig. $0,032<\alpha=$ 0,05 , artinya masyarakat umum lebih mengetahui tentang bank syariah. Seharusnya masyarakat santri yang lebih mengetahui tentang bank syariah dikarenakan masyarakat santri menuntut ilmu tentang muamalah secara khusus dan mempelajari hukum-hukum syariah dibandingkan masyarakat umum yang hanya memiliki ilmu tersebut secara umum.

Selain itu, terdapatnya perbedaan pengetahuan masyarakat umum dan masyarakat santri pada penelitian ini dilihat juga dari $\mathrm{t}_{\text {hitung }}>\mathrm{t}_{\text {tabel }}$ yaitu $2,170>1,984$. Artinya $\mathrm{H}_{1}$ diterima dan $\mathrm{H}_{0}$ ditolak karena adanya perbedaan pengetahuan antara masyarakat umum dengan masyarakat santri terhadap bank syariah. Dengan demikian dapat disimpulkan bahwa pada tingkat keyakinan 95\% pengetahuan masyarakat umum dan masyarakat santri terhadap bank syariah tidak memiliki perbedaan yang signifikan. Dari hasil penelitian ini, menunjukkan bahwa bank syariah lebih mendominasi masyarakat umum daripada masyarakat 
santri dalam hal sosialisasi dan informasi yang disampaikan oleh pihak bank syariah itu sendiri. Oleh karena masyarakat umum mempraktikkan secara langsung dengan menjadi nasabah sehingga masyarakat tersebut lebih mengetahui tentang bank syariah dibanding masyarakat santri yang mempelajari secara teori.

\section{PEMBAHASAN}

Bank syariah saat ini telah menerapkan prinsip syariah yang meliputi prinsip keadilan, kehati-hatian dan kejujuran dalam melaksanakan kegiatannya sebagai pemberi jasa keuangan kepada masyarakat. Prinsip keadilan yang sudah diterapkan dalam bank syari'ah yaitu berupa sistem bagi hasil, apabila diterapkan sistem yang berbasis riba sangat bertentangan dengan prinsip keadilan. Masyarakat umum dan masyarakat santri di kemukiman Bandar Baru yang menjadi responden dalam penelitian ini yakni masyarakat yang sudah berpendidikan SMP, SMA, D-III dan D-IV/S1. Mereka merupakan masyarakat yang memiliki pengetahuan tentang muamalah. Selanjutnya bagaimana pengetahuan masyarakat umum dan santri tentang bank syariah di Kemukiman Bandar Baru, yang selama ini bank syariah hanya ada di daerah Lhokseumawe dan jauh dari jangkauan masyarakat tersebut.

Hasil wawancara yang diperoleh oleh peneliti setelah melaksanakan penelitian terbagi kepada dua masyarakat, yaitu masyarakat umum dan masyarakat santri. Untuk penelitian terhadap masyarakat umum terdiri atas lima desa, yaitu desa Cot Jabet, Ulee Nyeue, Paya Uleue, Alue Keurinyai dan Jamuan. Hasil wawancara yang diperoleh dari keseluruhan desa yang ada di Kemukiman Bandar Baru yaitu yang memiliki tabungan, giro dan deposito di Bank Syariah sebanyak 33 orang atau $33 \%$. Alasan mereka memilih bank syariah bermacam-macam diantaranya karena bank syariah merupakan bank yang syar'i atau bank yang menerapkan prinsip syariah, karena pelayanannya bagus dan proses transaksinya lancar, ada juga karena untuk mengamankan uangnya, ada pula karena lebih menguntungkan dari pengambilan pembiayaan modal kerja sehingga dapat membantu masyarakat dalam mengatasi kelanjutan usahanya serta mereka menganggap bank syariah tidak mengandung riba atau memakai sistem bunga tetapi memakai sistem bagi hasil.

Selanjutnya yang memiliki tabungan, giro dan deposito pada Bank Konvensional sebanyak 38 orang atau $38 \%$. Alasannya mereka memilih bank konvensional dikarenakan bank tersebut mudah dijangkau atau lokasinya tidak jauh dari tempat tinggalnya/kampusnya, dan juga karena sudah membuka tabungan di Bank Konvensional semasa kuliah sehingga tidak ingin membuka lagi ditempat lain, ada yang menerima gaji bagi Pegawai Negeri Sipil dan Pegawai Swasta melalui bank tersebut dan ada pula yang menerima beasiswa bagi mahasiswa melalui bank konvensional. Akan tetapi, sebagian dari mereka yang memiliki tabungan di bank konvensional berminat untuk bergabung dengan bank syariah. Alasannya ingin menabung ditempat yang syar'i dan jauh dari riba.

Selain itu, masyarakat yang tidak memiliki tabungan, giro dan deposito baik bank syariah maupun bank konvensional sebanyak 29 orang atau 29\%. Alasannya karena belum membutuhkan untuk menabung di bank, ada yang tidak mengerti tentang bank, ada juga karena jauh tempat tinggalnya dari bank atau belum ada waktunya untuk menabung di bank dan harus bolak balik ke bank serta ada beberapa orang diantara mereka yang belum mempunyai penghasilan tetap seperti mahasiswa/i dan ibu rumah tangga. Biarpun begitu, sebanyak 15 orang atau $52 \%$ ingin bergabung dengan bank syariah agar di daerahnya berkembang syariah islam dan orang-orang tidak terusmenerus memakan riba, sedangkan 14 orang atau $48 \%$ ingin bergabung dengan bank konvensional.

Sementara masyarakat santri, yang memiliki tabungan, giro, dan deposito pada Bank syariah adalah teungku, ustadz dan ustadzah 25 orang atau $25 \%$. Alasan memilih bank syariah karena ingin mengembangkan bank syariah, karena ada keperluan pribadi untuk menyimpan gaji ataupun untuk menabung naik haji, menerima biaya anak yatim yang disalurkan oleh Baitul Mal melalui bank syariah dan untuk mendepositokan dana dayah agar terkelola dengan baik sehingga jauh dari praktik riba. Selanjutnya, yang memiliki tabungan, giro dan deposito pada Bank Konvensional sebanyak 20 orang atau $20 \%$. Alasannya karena menerima 
gaji lewat bank tersebut, lokasinya pun tidak jauh dari tempat tinggal, mudah dijangkau dan ada juga yang menerima beasiswa dari sekolahnya melalui bank konvensional sehingga membuat mereka harus menggunakan jasa bank tersebut. Sebagian dari masyarakat santri yang menggunakan jasa bank konvensional berminat untuk bergabung dengan bank syariah, karena menurut mereka bank syariah itu telah menjalankan usahanya sesuai dengan hukum syariah yang bersumber dari Al-Quran dan Hadits.

Kemudian yang tidak memiliki tabungan, giro dan deposito baik pada bank syariah maupun konvensional sebanyak 55 orang atau 55\% dan mayoritas yang tidak memiliki tabungan adalah para santriwan dan santriwati. Alasan mereka tidak memiliki tabungan karena masih menjadi tanggungan orang tua dan belum berpenghasilan sendiri sehingga mereka tidak membutuhkan tabungan di bank. Walaupun masyarakat santri tidak memiliki tabungan, giro dan deposito pada bank syariah sebanyak 35 orang atau 64\%, tetapi mereka berminat bergabung dengan bank syariah dikarenakan mereka percaya bahwa bank syariah melaksanakan kegiatannya sudah mendekati syariah dan terhindar dari riba. Selanjutnya, sebanyak 20 orang atau $36 \%$ ingin bergabung dengan bank konvensional dikarenakan bank tersebut mudah dijangkau oleh masyarakat santri.

\section{KESIMPULAN}

Berdasarkan penjelasan yang sudah dikemukakan pada bab sebelumnya maka diperoleh beberapa kesimpulan, yaitu sebagai berikut:

a. Wawancara yang dilaksanakan oleh peneliti dengan menggunakan kuesioner (angket) yang disebarkan kepada responden yaitu masyarakat umum dan masyarakat santri yang berada di Kemukiman Bandar Baru. Hasil wawancara yang diperoleh masyarakat umum yang memiliki tabungan, giro dan deposito pada bank syariah dan pada bank konvensional lebih banyak dari pada masyarakat santri. Adapun masyarakat umum yang tidak memiliki tabungan, giro dan deposito baik pada bank syariah maupun bank konvensional lebih sedikit dari pada masyarakat santri.

b. Terjadinya perbedaan antara pengetahuan masyarakat umum dan masyarakat santri terhadap bank syariah dapat dilihat dari nilai ratarata hasil kuesioner, yang menunjukkan bahwa nilai rata-rata masyarakat umum lebih tinggi dari pada masyarakat santri.

c. Dalam penelitian ini, hasil pengujian validitas dinyatakan valid dan uji reliabilitas dinyatakan realible.

d. Pengujian beda rata-rata terhadap masyarakat umum dan masyarakat santri berdasarkan hasil kuesioner terdapat perbedaan secara signifikan, artinya hasil tersebut lebih kecil dari pada tingkat signifikan yang ditentukan maka keputusannya adalah hipotess alternatif diterima dan hipotesis awal ditolak.

e. Berdasarkan hasil pengujian t test diketahui bahwa terdapat perbedaan antara pengetahuan masyarakat umum dan masyarakat santri terhadap bank syariah, sesuai dengan hasil hipotesis alternatif.

\section{SARAN}

Berdasarkan kesimpulan di atas maka hal yang dapat disarankan adalah sebagai berikut:

a. Kelemahan masyarakat umum dalam mendapatkan informasi terhadap bank syariah terdapat beberapa faktor, diantaranya sebagian masyarakat masih menganggap bank syariah sama dengan bank konvensional dan bank syariah juga mengandung riba. Hal tersebut juga dipersepsikan oleh masyarakat santri, karena sebagian dari mereka kurang mengetahui tentang bank syariah. Oeh karena itu, kurangnya pengetahuan masyarakat santri terhadap bank syariah memberikan peluang bagi bank syariah untuk melakukan sosialisasi yang baik sesering mungkin dan yang bermanfaat bagi mereka agar mereka tambah mengetahui dan berminat untuk bergabung dengan bank syariah.

b. Bagi kalangan akademisi, diharapkan penelitian ini dapat dijadikan informasi tambahan untuk Program Studi D-IV Keuangan dan Perbankan Syariah agar dapat diintegrasikan dalam pembelajaran terkait dengan Peng- 
etahuan Masyarakat Umum dan Masyarakat Santri Terhadap Bank Syariah.

c. Bagi penelitian mendatang hendaknya objek penelitiannya lebih diperluas lagi, sehingga Pengetahuan Masyarakat Umum dan Masyarakat Santri terhadap bank syariah akan lebih luas lagi. Disamping itu, pada dasarnya masih banyak dampak negatif dari Bank Syariah terhadap masyarakat.

d. Bagi penelitian mendatang hendaknya instrumen penelitian lebih diperdalam dan dikembangkan lagi, sehingga kemampuan mengukurnya lebih baik dan dalam pembuatan kuesionernya lebih bagus agar masyarakat mudah memahami dan mengerti. 


\section{REFERENSI}

Anonymos (2001). Wahana Komputer Tim Penelitian dan Pengembangan Pengolahan Data Statistik dengan SPSS 10.0. Salemba Infotek. Jakarta.

(2014). Tim Asisten Dosen Statistika FEB UNPAD, Modul Statistika I. Fakultas Ekonomi Dan Bisnis, Universitas Padjadjaran

Antonio, Muhammad Syafi’i (2001). Bank Syariah dari Teori ke Praktik. Gema Insani. Jakarta.

Arikunto, Suharsimi (2006). Prosedur Penelitian Suatu Pendekatan Praktik. PT Asdi Mahasatya. Jakarta.

Badan Pusat Statistik (2013). Aceh Dalam Angka. BPS. Provinsi Aceh. (2013). Kecamatan Banda Baro Dalam Angka. BPS Aceh Utara. Aceh.

Bungin, Burhan (2005). Metodelogi Penelitian Kuantitatif, Et al. Kencana. Jakarta.

Karim, Adiwarman A. (2007). Bank Islam:Analisis Fiqih dan Keuangan. PT. Raja Grafindo Persada. Jakarta.

Kusdariati, Yayak (2013). Pengaruh Pengetahuan Santri Tentang Perbankan Syariah Terhadap Minat Memilih Produk Bank Syariah Mandiri Yogyakarta (Studi Kasus Santri PP. Nurul Ummah Putri Kotagede Yogyakarta). Skripsi Strata Satu (S1). Program Studi Keuangan Islam, Fakultas Syariah dan Hukum, Universitas Islam Negeri Sunan Kalijaga. Yogyakarta.

Narbuko, Cholid dan Abu Achmadi (2004). Metodologi Penelitian. PT. Bumi Aksara. Jakarta.

Notoatmodjo, S. (2003). Metodologi Penelitian Kesehatan. PT Rineka Cipta. Jakarta.

Nursalam. (2003). Konsep dan Penerapan Metodologi Penelitian Ilmu Keperawatan. Salemba Medika. Jakarta.

Purwanto (2008). Metodologi Penelitian Kuantitatif Untuk Psikologi dan Pendidikan. Pustaka Pelajar Celeban Timur UH III/548. Yogyakarta.

Republik Indonesia (2008). Undang-Undang Republik Indonesia Nomor 21 Tahun 2008 Tentang Perbankan Syariah. Bank Indonesia. Jakarta.

Sugiyono (2006). Metode Penelitian Kuantitatif, Kualitatif, R\&D. ALFABETA, cv. Bandung. , (2007). Metode Penelitian Kuantitatif, Kualitatif, R\&D. ALFABETA, cv. Bandung. (2009). Statistika Untuk Penelitian. ALFABETA, cv. Bandung.

Sumitro, Warkum (2002). Asas-asas Perbankan Islam dan Lembaga-Lembaga Terkait (BMI dan Tafakul di Indonesia). PT Raja Grafindo. Jakarta.

Yaya, Rizal., dkk (2009). Akuntansi Perbankan Syariah:Teori dan Praktik Kontemporer. Salemba Empat. Jakarta. 